\title{
Relative Influences of Review and Engagement Auditor Rotation on Audit Quality: Evidence from China
}

\author{
Sang Ho Kim* and Jianqun Xi
}

\begin{abstract}
Manuscript type: Research paper

Research aims: This study focuses on the effects of audit partner rotation on audit quality (AQ) in China. In particular, we examine the effects of review auditors (RAs) and engagement auditors (EAs) on $\mathrm{AQ}$ when they voluntarily and mandatorily rotate.

Design/Methodology/Approach: The data in this study are retrieved from the Chinese Stock Market and Accounting Research (CSMAR) database. We develop an OLS regression model and logit model respectively to test the hypotheses developed. Finally, we have 13,856 firm-year observations collected for the first regression model, and 16,893 firm-year observations gathered for the second logit model from 2003 to 2015.

Research findings: Findings show that RAs are more likely to behave opportunistically to retain clients by weighing up the benefits and costs of compromising audit quality in the first year after a rotation. The results imply that RAs may have an incentive to acquiesce the clients' accounting irregularities in their first year of audit engagement when they are mandatorily rotated. However, we do not find this trend in terms of EAs' rotation, suggesting that EAs are less affected by the auditor-client relationship compared to RAs.
\end{abstract}

\footnotetext{
* Corresponding author: Sang Ho Kim is an Assistant Professor in Accounting at International Business School Suzhou, Xi'an Jiaotong-Liverpool University, China. Email: Sangho.Kim@ xjtlu.edu.cn

Jianqun $\mathrm{Xi}$ is an Assistant Professor at Division of Business and Management, United International College, Beijing Normal University-Hong Kong Baptist University, China. Email: jianqunxi@uic.edu.hk
}

https:// doi.org/10.22452/ajba.vol14no1.7 
In addition, we find that RAs are less likely to issue modified audit opinions (MOPI) as the magnitude of negative discretionary accruals (DA) increases when they are voluntarily rotated.

Theoretical contribution/Originality: Previous studies have investigated the relationship between mandatory audit partner rotation and audit quality. The results are mixed and inconclusive. Our study contributes to the extant literature by considering RAs' opportunistic behaviour after mandatory rotation, which has not been explored in previous studies. In China, only a few studies have examined the relationship between mandatory audit partner rotation and audit quality. Our study is one of the first study focusing on the RA's influence on AQ.

Practitioner/Policy implication: The findings of our study can help Chinese authorities, listed firms and academics gain more understanding on whether mandatory audit partner rotation improves audit quality in practice. Since RAs have greater incentive to retain the existing client, we propose that RAs should bear more responsibility for the audit work, instead of the equally shared responsibility with EAs.

Research limitation/Implications: Our study is subject to some limitations. First, our study adopts the performance-adjusted discretionary accruals as a proxy for audit quality. However, there can be a measurement error in estimating discretionary accruals. Second, we focus on the auditor rotation and exclude the case of audit firm rotation. Since the AQ can be affected by various factors, audit firm rotation can also affect $A Q$. Third, although we test the relative effects of RAs and EAs in audit work, we do not examine the effect of RAs' characteristics such as their professional experience, educational background, and years of service. AQ can be affected by RAs' characteristics.

Keywords: Auditor Rotation, Audit Quality, China, Review Auditors, Engagement Auditors

JEL Classification: G0

\section{Introduction}

In 2003, the China Securities Regulatory Commission (CSRC) and the Ministry of Finance (MOF) jointly issued a new policy requiring auditors who sign an audit report to be rotated off after five consecutive years of audit engagement for the same client firm. Although several jurisdictions have imposed mandatory rotation for audit partners, the Chinese auditing regulations are deemed to be unique in the following 
several aspects. First, the related policy mandates that two auditors (i.e., review and engagement audit partner) are required to sign the audit report and share equal legal responsibility for any audit failure. Second, it is also stipulated that among those two signing auditors, either engagement or review partners must rotate off following five consecutive years of audit engagement for the same auditee. Third, the Chinese authorities require the signing auditors' names to be disclosed so that the review auditor (RA) and engagement auditor (EA) can then be identified separately.

Under this dual auditorship practice, EA is usually involved in all phases of the audit process including the fieldwork, while RA chiefly conducts a final review of the audit report (e.g. Firth et al., 2012; Wang, $\mathrm{Yu}$, \& Zhao, 2015). We pay more attention to the relative roles and influences of RA and EA within the same audit firm on audit quality. In China, RAs are usually the senior and more experienced partners in audit firms, while EAs are relatively junior (Lennox et al., 2014; Wang, $\mathrm{Yu}$, \& Zhao, 2015). The recent behavioural research has suggested that auditors are susceptible to a variety of social pressures such as obedience pressure generated from the superior or conformity pressure generated from the colleagues (e.g. DeZoort \& Lord, 1994; Davis et al., 2006; Clayton \& Staden, 2015). Especially, Brink et al. (2016) indicated that Chinese auditors were more sensitive to the obedience pressure generated from the auditor's superiors than the conformity pressure generated from the auditor's colleagues. Obedience pressure theory stipulates that individuals become less responsible for their actions when they move from an autonomous state to an agentic state (e.g. Milgram, 1974). Furthermore, Zhao et al., (2020) demonstrated that the outgoing auditors were likely to hide the negative information regarding the client before the mandatory rotations, while the incoming auditors were likely to disclose the negative information following the mandatory rotation. They also documented that this trend was more pronounced in the RA group rather than the EA group. Both Brink et al. (2016) and Zhao et al. (2020) showed that RA's influence on audit quality could be greater than EA's influence in China. Liu (2017) demonstrated that there were positive associations between audit fee and auditors' ranks in an audit firm, and the busyness of auditors. According to DeAngelo (1981), an auditor may compromise the audit independence to retain the client in subsequent periods because the client-specific quasi-rents become greater as the auditor's tenure increases. We conjecture that RAs have a greater incentive to retain existing clients because they are relatively 
seniors in the audit firm, and their financial benefit is tied with audit fee (Lennox et al., 2014; Liu, 2017). Thus, they are more likely to compare the benefits and costs of acquiescing to client's accounting irregularities compared with EAs. This study demonstrates that the mandatory rotation of RA is significantly associated with the absolute value of discretionary accruals $\left(\mathrm{ABS}_{\mathrm{DA}}\right)$ and negative discretionary accruals (DA), indicating that RAs are more likely to compromise the audit quality when they rotate mandatorily. Moreover, we find that RAs are less likely to issue modified audit opinions (MOPI) as the magnitude of negative DA increases when they are voluntarily rotated.

This study contributes to the body of existing literature in the following ways. First, this study provides new evidence pertinent to the ongoing debate over the effects of mandatory rotation of audit partners on audit quality. The results in this study show that the mandatory rotation rule can be differently adapted in China depending upon the audit partners' roles - i.e. whether the auditor is an RA or EA (e.g., Carson et al., 2014; Chi \& Huang, 2005; Chi et al., 2009; Chen et al., 2008). Second, previous studies on the topic of audit partner rotation have heavily focused on the EAs' attributes, such as their tenure or industry expertise, because they conduct the majority of the audit work (e.g., Carey \& Simnett 2006; Chen et al., 2008; Wang et al., 2015; Wang, $\mathrm{Yu}, \&$ Zhao, 2015). However, the influences of an RA on audit quality have rarely been investigated in previous empirical studies. Third, the findings of this study also provide useful implications for the Chinese policymakers regarding the dual auditorship system. Although the Chinese authorities have been implementing this system since 2003, the extant empirical evidence (e.g. Lennox et al., 2014; Wang et al., 2015; Wang, Yu, \& Zhao, 2015) provide little feedback on how this dual auditorship works within the regulatory framework. If authorities are more informed by academic research, they could design a more sophisticated regulatory framework to improve the audit quality.

This study aims to add empirical evidence to the ongoing debate about the effectiveness of audit partner rotation on audit quality in China. The findings of previous studies are mainly focused on the significant influence of EAs on audit quality (e.g. Wang et al., 2015; Wang, Yu, \& Zhao, 2015; Gong et al., 2017) in China. However, they have not paid sufficient attention to RA's influence on audit quality. Our study intends to fill this gap. Chinese regulations stipulate that both RA and EA are required to sign their names on audit reports and thanks to the database in this study, we can identify RAs' and/or EAs' mandatory or voluntary 
rotations (see the "measurement of key variables"). The rest of this paper is organised as follows; the next section provides a literature review and hypotheses. Section 3 explains the methodology, while Section 4 offers a discussion on the main results. Section 5 concludes the study.

\section{Theoretical Framework, Literature Review and Hypothesis Development}

\subsection{The Effects of Audit Partner and Audit Firm Rotation on Audit Quality}

DeAngelo (1981) argued that client-specific start-up costs and the transaction costs of switching auditors tend to give rise to quasi-rents in subsequent audits. The threat of losing these quasi-rents puts pressure on incumbent auditors to acquiesce to clients' accounting irregularities in order to retain the existing clients during subsequent periods. Therefore, the longer the auditor tenure, the greater the incentives to compromise audit quality that the auditor may have. However, prior research done on audit partner rotation is quite limited because only a few jurisdictions require the name of the lead engagement partner to be disclosed (Stewart et al., 2016).

Despite this limitation, a number of studies have examined the influences of auditor tenure on audit quality. For instance, Manry et al. (2008) conducted a study using US data on the relationship between audit partner tenure and audit quality proxied by DA. They found that auditor partner tenure did not affect audit quality in most cases, with the exception of small firms possessing greater than seven years of audit tenure, which showed a negative association between auditor tenure and audit quality. Litt et al. (2014) also documented a poor reporting quality in the first two years after audit partner rotation, implying the loss of client-specific knowledge. In brief, these US based studies cast doubt as to the effectiveness of audit partner rotation requirements on audit quality. Further, Australian and Taiwanese legislations stipulate that auditors' names should be disclosed (Cameran et al., 2015). Using Australian firm data, Carey and Simnett (2006) reported that an auditors' tenure was negatively associated with the propensity to issue an ongoing concern or opinion, but was positively associated with the propensity of beating or missing earnings benchmarks.

Based on Taiwanese firm data, Chi and Huang (2005) tested the effects of auditor rotation and audit firm rotation on audit quality. 
They argued that there was a trade-off between the incremental effects of the learning experience and the excessive familiarity. Their empirical results indicated that a tenure of five years was a suitable threshold for this trade-off. That is to say, audit quality is likely to improve within the first five years of a certain auditor's tenure, but deteriorate after that period. They also argued that audit firm tenure was more critical to the audit process than the auditor tenure was in terms of transition of the learning experience. In addition, Chen et al. (2008) found the existence of a significant negative relationship between auditor tenure and DA, implying that lengthier auditor tenure may improve audit quality. However, Chi et al. (2009) documented mixed results, indicating that mandatory audit partner rotation may or may not affect audit quality. Apart from the aforementioned countries, Italy, Spain and several other European countries also impose a 7-year threshold for mandatory rotation of audit partner (Cameran et al., 2015).

\subsection{The Mandatory Auditor Rotation in China}

China is one of the few countries that require mandatory rotation of audit partner following five consecutive years of the audit engagement, a requirement imposed beginning in 2003 (Cameran et al., 2015). Both RAs and EAs must sign audit reports and bear equal legal liability. In practice, however, RAs and EAs perform different roles during an audit; the EA is actively involved in all phases of the audit, while the RA conducts the final review of the audit procedure. Moreover, these auditor's names are disclosed in all audit reports. According to Lennox et al. (2014), two auditors' signatures appear on the audit report, the RA's being on the top and the EA's at the bottom. ${ }^{1}$ Generally, audit partners identified as RAs have significantly more experience than those identified as EAs in terms of the partner's age, the partner's service years following CPA qualification, and the number of signed audit reports for listed firms.

In China, few studies have investigated the effects of audit partner and/or audit firm rotation on audit quality. Firth et al. (2012) found that mandatory audit partner rotation had no significant influence on audit quality except for institutionally underdeveloped regions, where

\footnotetext{
${ }^{1}$ Lennox et al. (2014) found that among the two auditors' signatures in the audit report, the top one is signed by the review partner and the bottom one by the engagement partner (see footnote number 10 at page 1,784 in Lennox et al., 2014).
} 
mandatory rotation of auditors was shown to improve audit quality. Although they recognised two signing auditors in firms' annual report, they did not separate RAs from EAs. Therefore, their findings are regarded as the combined effects of both RA and EA rotations. Lennox et al. (2014) examined the relationship between mandatory audit partner rotation and audit quality using proprietary audit adjustment data. Their results indicated that mandatory EA rotation improved the audit quality in the year immediately surrounding rotation. However, they failed to find any significant association between audit adjustment and an RA's rotation. They separately identified the effects of RA and/ or EA rotations in test models. Yet, these findings were difficult to be generalised as they used the proprietary dataset.

Later, Wang, Yu and Zhao (2015) investigated the association between audit partner quality and audit failure rate as measured by the total number of audit failures associated with an audit partner divided by the total number of audit reports signed by the same partner. They concluded that EA's past audit failure rate was positively associated with the probability that the current year annual report was subsequently restated. More recently, Gong et al. (2017) found that EA's negative experiences were significantly associated with higher costs of corporate bonds using Chinese data. They defined the EA's negative experience as the case of audit failure or the case of sanction imposed on the clients due to corporate fraud. Both Wang, $\mathrm{Yu}$ and Zhao (2015) and Gong et al. (2017) mainly focused on the influences of EA's characteristics on audit quality rather than RA's influence. Zhao et al. (2020) examined the impact of mandatory audit partner rotation on negative information hoarding in Chinese auditors. They documented that the outgoing auditors were likely to hoard the negative information before the mandatory rotation, while the incoming auditors were likely to disclose the negative information following the mandatory rotation. Church et al. (2020) demonstrated that auditor narcissism was positively associated with audit delay and negatively associated with client's discretionary accruals, implying that auditor's characteristics can also affect the audit quality in China.

\subsection{The Relative Roles and Influences of RA and EA}

The behavioural accounting research (e.g. DeZoort \& Lord, 1994; Davis et al., 2006; Clayton \& Staden, 2015; Brink et al., 2016) has raised the concerns of the influences from the senior auditors during the auditing 
process. These studies suggest that auditors are subject to a variety of social pressures that can affect their judgements. For example, DeZoort and Lord (1994)'s experiment showed that the auditors who received inappropriate instructions from their superiors were more likely to violate professional norms and standards compared with auditors under no such pressure, indicating the existence of obedience pressure. Moreover, they found that the pressure from a partner had a significantly greater effect on judgements than pressure from a manager. Milgram's (1974) 'obedience to authority' theory states that under obedience pressure, individuals move from an autonomous state to an agentic state and they feel less responsibility for their actions, thereby exercising less introspection than they would in an autonomous state. Thus, if EA believes that the superior (i.e., RA) is a legitimate source of authority, RA's opinion could become more influential than EA's judgment. Brink et al. (2016) examined whether estimate source interacts with social pressure in Chinese audit firms. The fair value estimate was a very complex process by nature and it was difficult to detect when the estimates were manipulated by the firm. Thus, Chinese auditor should pay sufficient attention to secure the reliability of the fair value estimate's source. Brink et al. (2016) postulated that Chinese auditors may be more sensitive to various social pressures than auditors from other culture because of the high degree of power distance and collectivism embedded in Chinese culture (Hofstede, 1980; 1991). The experimental results showed that Chinese auditors' risk assessments and their decisions on the further investigation were not influenced by relevant information about a fair value estimate's source when advised to use a questionable estimate by a superior. By contrast, when the same advice was received from a peer, the likelihood of further investigation and auditors' risk assessments are impacted by the estimate's source. These findings were well-contrasted to Clayton and Staden (2015)'s study which reported that Australian and New Zealand auditors were affected by both obedience pressure from their superiors and conformity pressure from their colleagues when they were making ethical judgements. Given that the senior auditor would be RA and the junior auditor would be EA in audit work (Lennox et al., 2014), it is plausible that EAs are exposed to a significant level of obedience pressure from their superior (i.e., RAs) in Chinese audit firms (e.g. Du \& Lai, 2018; Church et al., 2020; Xiao et al., 2020; Zhao et al., 2020). Chen et al. (2010) demonstrated that Chinese auditors were more likely to compromise audit quality for an economically important client and 
Liu (2017) documented a positive association between the audit fee and the auditor's partner position and busyness in China. Therefore, if RA's financial benefits are tied with audit contract and they can exercise greater influence on audit quality compared to EA, they may have an incentive to retain the important client to earn quasi-rents and save the audit cost by conducting a subsequent audit work (DeAngelo, 1981).

\subsection{Hypotheses Development}

The majority of previous research has investigated the effects of audit partner and/or audit firm rotations on audit quality, with little attention paid to the functions of Chinese dual auditorship regimes (e.g. Wang, $\mathrm{Yu}, \&$ Zhao, 2015). We posit that although both RA and EA are required to sign an audit report in China, their hierarchal roles and influences may vary and their incentives may affect the audit quality differently (Lennox et al, 2014; Wang, Yu, \& Zhao, 2015).

As a body of behavioural research indicates, there is a significant level of obedience pressure generated from the superiors in Chinese audit firms (e.g. DeZoort \& Lord, 1994; Davis et al., 2006; Clayton \& Staden, 2015; Brink et al., 2016). Although RAs are able to affect an audit quality by exercising their influence, the previous empirical studies have largely underestimated or ignored the influence of RAs in audit procedure. Previous research have shown that there are substantial setup costs for new client in terms of audit fee, audit report lag, and audit efforts (Sharma et al., 2017; Xiao et al., 2020; Church et al., 2020). Liu (2017) also documented that audit fee was positively associated with auditor's position as a partner and busyness, which were relevant characteristics to RAs rather than EAs. Thus, if the RAs rank highly in terms of a senior position in an audit firm, they may have a greater incentive to retain the existing client compared with EAs in the first year of rotation (DeAngelo, 1981). When confronting a client's accounting irregularities, RAs are more likely to behave opportunistically by weighing up the benefits and costs of compromising audit quality, while EAs are less likely to be affected by such incentive. Thus, we first test the effect of RA's and EA's rotation on audit quality, as proxied by DA. Then, we split auditor rotation into categories of mandatory auditor rotation or voluntary auditor rotation in order to capture the different effects on audit quality. Therefore, our first hypothesis is as follows:

$\mathrm{H}_{1}$ : The rotation of audit partners has an effect on audit quality. 
$\mathrm{H}_{1 \mathrm{a}}$ : The mandatory or voluntary rotation of an RA has an effect on audit quality.

$\mathrm{H}_{1 \mathrm{~b}}$ : The mandatory or voluntary rotation of an EA has an effect on audit quality.

Badertscher et al. (2009) argued that a firm has an incentive for negative DA so as to reduce corporate tax burden, to smooth earnings, to create a 'cookie jar' of reserves, or to avoid government intervention in asset allocation (also known as the "political cost hypothesis"). In reality, Chinese stock exchanges have imposed a series of rigorous regulations such as mandatory delisting rules and seasoned equity offering rules (e.g. Cheng et al., 2010). ${ }^{2}$ Consequently, Chinese firms may have a greater incentive for upward DA rather than downward DA. However, these positive DA adjustments may draw greater attention from regulators, thereby raising the cost of compromising audit quality compared with negative DA (Kim et al., 2004). From an RA's perspective, the associated costs of exercising his/her influence may be cheaper in the negative DA case as compared with the positive DA case, thereby making the RA's influence more pronounced in a negative DA sample rather than a positive DA sample. Thus, our second hypothesis is as follows:

$\mathrm{H}_{2}$ : The rotation of audit partners has an effect on positive and/or negative DA.

$\mathrm{H}_{2 \mathrm{a}}$ : The mandatory or voluntary rotation of an RA has an effect on positive and/or negative DA.

$\mathrm{H}_{2 \mathrm{~b}}$ : The mandatory or voluntary rotation of an EA has an effect on positive and/or negative DA.

Our third hypothesis is developed in order to test the moderating effects of audit partner rotation on the association between MOPI and DA. DeAngelo (1981) defines an audit quality as the joint probability that an auditor discovers a breach in the client's accounting system and subsequently reports that breach. Consistent with DeAngelo (1981) and Lennox et al. (2014), we posit two stages in the audit process. In the first stage, auditors conduct an audit in order to detect potential financial misstatements. If accounting irregularities were spotted in the first

\footnotetext{
2 If a firm reports two years' consecutive losses, it is labelled as 'special treatment' and the daily price limit set to $\pm 5 \%$. If a firm reports three years' consecutive losses, it is labelled as 'particular transfer' with suspension of stock trading.
} 
stage, auditors would consider the type of audit opinion depending on the client's response to a proposed accounting adjustment in the second stage. We attempt to measure audit quality as a joint probability of detecting a firm's accounting irregularities proxied by DA level, and reporting those accounting irregularities proxied by a propensity of issuing a MOPI (e.g. Firth et al., 2012). Chen et al. (2010) demonstrated that the probability of issuing MOPI was significantly lower for clients that are more important to individual auditors in China. If an auditor has an incentive to secure the subsequent audit, they are more likely to acquiesce to the demands of specific clients and restrain themselves from issuing MOPI (e.g. DeAngelo, 1981; Carey \& Simnett 2006; Chen et al., 2010; Firth et al., 2012; Xiao et al., 2020). As shown in Zhao (2020), RAs showed more negative information hoarding compared to EAs. Therefore, we posit that the RAs are more reluctant to issue a MOPI as they have a greater incentive to retain client-specific quasi-rents compared with EAs following the rotation.

$\mathrm{H}_{3}$ : The rotation of audit partners moderates the association between DA and MOPI.

$\mathrm{H}_{3 \mathrm{a}}$ : The mandatory or voluntary rotation of RAs moderates the association between DA and MOPI.

$\mathrm{H}_{3 \mathrm{~b}}$ : The mandatory or voluntary rotation of EAs moderates the association between DA and MOPI.

\section{Methodology}

\subsection{Sample}

We collected all financial and audit data from the Chinese Stock Market and Accounting Research (CSMAR) database. The CSMAR database is a comprehensive database providing not only Chinese firms' financial statements, but also other information including stock market data, audit opinions, and detailed information related to audit firms and the signing auditors. All sampled firms are A-share listed firms on the Shanghai Stock Exchange (SHSE) and the Shenzhen Stock Exchanges (SZSE). In accordance with prior research, we excluded the financial sector. Due to requirements for mandatory auditor rotation, which has been in effect since 2003, we constructed our dataset beginning in 2003 in line with previous research (e.g., Firth et al., 2012). We developed two different test models for use in this study: the first test model is a regression model for $\mathrm{H}_{1}$ and $\mathrm{H}_{2}$, and the other one is a logit model for $\mathrm{H}_{3}$. 
As a result, a total of 13,856 firm-year observations were collected for the first regression model, and 16,893 firm-year observations were gathered for the second logit model for the period of 2003 to 2015.

\subsection{Measurement of Key Variables}

The CSMAR database provides information for both signing auditors and audit firms in China. First, we defined audit firm rotation in a similar manner to Firth et al. (2012). If the audit firm in year $t$ is different from the previous one in year $t-1$, we identified this case as an audit firm rotation. We did not consider simple changes in an audit firm's name or audit firm merger as a change in audit firms. Since our research interest in this study is the effects of audit partner rotation (within the same audit firm) rather than audit firm rotation, we excluded the case of audit firm changes from the test model.

Next, if there is no change in audit firm then we identified the change of audit partners as the audit partner rotation. The CSMAR provides both signing auditors' names, and we also confirm that the first signing auditor's name in the database is the top signing auditor's name, as well as that the second name is the bottom signing auditor's name in the actual audit report. ${ }^{3}$ To be consistent with previous studies conducted by Lennox et al. (2014) and Wang et al. (2015), we designated the first signing auditor's name as RA and the second one as EA. Then, we counted the consecutive years of the same auditor's name in each financial year after 2003 to determine the given audit partner's tenure. Therefore, the audit partner's tenure in this study is indicative of the consecutive years of auditor engagement for the same client, without an audit firm change.

If an auditor's tenure for the same client reaches the fifth year, then we identified the next year's incoming auditor change as a mandatory audit partner rotation. ${ }^{4}$ All other audit partner rotations were classified as voluntary ones. For example, if an audit partner rotates off before the fifth year, and the incoming audit partners (within the same audit

\footnotetext{
${ }^{3}$ The first auditor's name in the database is identical to review partner's name in the actual audit report, and the second auditors' name is matched with engagement partner's name.

${ }^{4}$ According to the regulation, in a certain condition, the auditor can extend his/her audit tenure one more year, leading to the total tenure as six years. See Firth et al. (2012, p. 116): "If both of the signing auditors have provided audit services for the same entity for five consecutive years during the same period, one of them is allowed to extend to a maximum of one more year their position as a signing auditor of the entity concerned."
} 
firm) take over the audit in the following year, such a case was classified as a voluntary audit partner rotation. Therefore, we were able to separate auditor types (i.e., RAs or EAs) together with rotation status (i.e., mandatory or voluntary). To be more specific, the audit partner rotations were classified as one of these four types: mandatory review partner rotation (MRR) was defined as if the incoming auditor replaces the auditor on reviewer position who had conducted as either a review and or an engagement auditor for the past 5 consecutive years. Similarly, mandatory engagement partner rotation (MER) was defined as if the incoming auditor replaced the auditor on engagement position who had conducted as either a review and or an engagement auditor for the past 5 consecutive years; other cases were defined as voluntary engagement partner rotation (VER) and voluntary review partner rotation (VRR).

\subsection{Discretionary Accruals as Proxy for Audit Quality - the First Test Model}

A number of studies have considered the level of DA as a proxy for audit quality, including Chi and Huang (2005), Chen et al. (2008), Chi et al. (2009), Manry et al. (2008) and Kim et al. (2004). This study adopts a performance-adjusted modified Jones model, as suggested by Kothari et al. (2005), in order to calculate DA. This model incorporates the firm performance (proxied by ROA) into the modified Jones model. Thus, it enables us to control the impact of the extreme performance of firms, which might be ignored in the modified Jones model (DeChow et al., 1995). In the model, a firm's total accruals are defined as the difference between net income and net cash flow from operation. Then, total accruals are decomposed into non-discretionary accruals and discretionary accruals (i.e., DA). Non-discretionary accruals are estimated as follows;

$$
\frac{\text { Accruals }_{t}}{T A_{t}}=\alpha_{0}\left(\frac{1}{A_{t-1}}\right)+\alpha_{1}\left(\frac{\Delta \text { Sales }_{t}-\Delta A R_{t}}{A_{t-1}}\right)+\alpha_{2}\left(\frac{P P E_{t}}{A_{t-1}}\right)+\alpha_{3} R O A_{t}+\varepsilon_{t}
$$

where Accruals = total accruals calculated as the difference between net income and net cash flow from operation,

$\triangle$ Sales $=$ the change in recorded sales,

$\triangle A R=$ the changes in net receivables,

$P P E \quad=$ the property, plant, and equipment,

ROA = the net income divided by the lagged total assets. 
As a result, DA can be calculated as the difference between the total accruals and estimated non-discretionary accruals.

In line with previous studies (e.g. Chi \& Huang 2005; Chen et al., 2008; Cheng et al., 2010; Firth et al., 2012; Lennox et al., 2014; Manry et al., 2008; Wang et al., 2015; Wang, Yu, \& Zhao, 2015; Zhao et al., 2020), we employed several control variables. SIZE (the natural log of total assets) was used to control the sizes of sampled firms. CFO (cash flow from operations) was adopted to control a given firm's cash level, which may affect the level of DA. GRW (net sales growth) and BM (book to market value ratio) were adopted to control a given firm's growth rate. LEV (debts to asset ratio) and AGE (firm age) were used to control the firm leverage ratio and firm age, respectively (e.g., Chi \& Huang, 2005; Firth et al., 2012; Lennox et al., 2014; Zhao et al., 2020). We also controlled the effects of audit firms by adopting TOP 8 (Top 8 audit firms in China) and FTEN (audit firm tenure after 2003). In order to reflect key features of the Chinese capital market, a series of control variables were also adopted such as SOE (state-owned enterprise), SPT (special treatment firms), LOSS (loss reporting firm in year $t-1$ ), and $N E W$ (seasoned equity offering in year $t+1$ ) (e.g., Cheng et al., 2010; Manry et al., 2008; Wang et al., 2015). Lastly, PEIND (ratio of independent directors on the board), CONT (ownership percentage of the controlling shareholder), and EMOTS (natural log of total emolument of Top 3 directors, supervisors and executives) were applied so as to control corporate governance factors that may affect the level of DA (e.g., Cheng et al., 2010; Wang et al., 2015; Wang, Yu, \& Zhao, 2015; Zhao et al., 2020).

The first test model is written as follows:

$$
\begin{aligned}
A B S_{D A}(\text { or } D A)= & \beta_{0}+\beta_{1} M R R+\beta_{2} V R R+\beta_{3} M E R+\beta_{4} V E R+\beta_{5} S I Z E+ \\
& \beta_{6} C F O+\beta_{7} G R W+\beta_{8} B M+\beta_{9} L E V+\beta_{10} A G E+ \\
& \beta_{11} T O P 8+\beta_{12} F T E N+\beta_{13} S O E+\beta_{14} S P T+\beta_{15} L O S S+ \\
& \beta_{16} N E W+\beta_{17} \text { PEIND }+\beta_{18} C O N T+\beta_{19} E M O T 3+\varepsilon
\end{aligned}
$$

Table 1 is provided to highlight the summary of the variables used in equation (2).

\subsection{Modified Audit Opinion as Proxy for Audit Quality - the Second Test Model}

We conjectured that the level of DA would be jointly determined through interactions between the preparer (client firm's management) and auditor 
Table 1: Variables and Definitions for Equation (2)

Variable Definition

Type of

Variable

$\mathrm{ABS}_{\mathrm{DA}}$ The absolute value of discretionary accruals computed

Dependent using a performance adjusted modified Jones model (Kothari et al., 2005)

DA Discretionary accruals computed using a performance adjusted modified Jones model (Kothari et al., 2005)

MRR A dummy variable that takes the value of 1 if the incoming auditor replaces the auditor on reviewer position who has served as a reviewer and or engagement auditor for the past 5 consecutive years, 0 for otherwise

VRR A dummy variable that takes the value of 1 if the incoming auditor replaces the auditor on reviewer position who has served as a reviewer and or engagement auditor for less than 5 consecutive years, 0 for otherwise

MER A dummy variable that takes the value of 1 if the incoming auditor replaces the auditor on engagement position who has served as a reviewer and or engagement auditor for the past 5 consecutive years, 0 for otherwise

VER a dummy variable that takes the value of 1 if the Independent incoming auditor replaces the auditor on engagement position who has served as a reviewer and or engagement auditor for less than 5 consecutive years, 0 for otherwise

Dependent Independent Independent Independent

\begin{tabular}{ll}
\hline SIZE & The natural log of total assets \\
CFO & Operating cash flows (earnings before extraordinary
\end{tabular}

Control items less total accruals) divided by lagged total assets

GRW Net sales growth

Control

BM Book to market value ratio

Control

LEV Debt to asset ratio

Control

AGE Number of years since the establishment

Control

TOP8 A dummy variable that takes the value of 1 if the

Control auditor is one of the Top 8 audit firms in China,

Control 0 for otherwise

FTEN Audit firm tenure after 2003

Control

SOE A dummy variable that takes the value of 1 if the

Control controlling shareholder is a state-owned enterprise (SOE), 0 for otherwise.

SPT A dummy variable that takes the value of 1 if the firm is classified as a 'special treatment firm', 0 for otherwise

LOSS A dummy variable that takes the value of 1 if the firm reported a loss in the previous year, 0 for otherwise 
Table 1: Continued

Variable Definition

Type of

Variable

\begin{tabular}{lll}
\hline NEW & $\begin{array}{l}\text { A dummy variable that takes the value of } 1 \text { if the firm } \\
\text { conducts a seasoned equity offering in the following }\end{array}$ & Control \\
year, 0 for otherwise & \\
PEIND & $\begin{array}{l}\text { The number of independent directors divided by the } \\
\text { total number of directors }\end{array}$ & Control \\
CONT & $\begin{array}{l}\text { The ownership percentage of the ultimate controlling } \\
\text { shareholder }\end{array}$ & Control \\
EMOT3 & $\begin{array}{l}\text { The natural log of total emolument of Top } 3 \text { directors, Control } \\
\text { supervisors and executives }\end{array}$ & \\
\hline
\end{tabular}

partners (DeAngelo, 1981). Thus, a MOPI will be issued when auditors detect a significant misstatement (i.e., to discover a breach), but the preparer refuses to correct the misstatement (i.e., to report that breach). Therefore, the propensity for issuing a MOPI was applied for the measurement audit quality in the second model in order to investigate the moderating effects of audit partner rotations under a given level of DA.

Previous studies (e.g. Chen et al., 2010; Firth et al., 2012; Lennox et al., 2014) have shown that the financial risks and financial status can also impact the frequency of issuing MOPI. Thus, in the second test model, we included three variables to control those factors. QUICK represents the quick ratio. NAR is a ratio of net account receivables divided by total assets and INVEN is the ratio of net inventory divided by total assets, respectively. Thus, a quick ratio (QUICK) is expected to be negatively associated with MOPI, while both NAR and INVEN are expected to be positively associated (Firth et al., 2012). All other variables are the same as previously defined.

The second test model is written as follows:

$$
\begin{aligned}
\operatorname{Logit} p(M O P I)= & \beta_{0}+\beta_{1} A B S_{D A}(\text { or } D A)+\beta_{2} M R R+\beta_{3} V R R+\beta_{4} M E R+\beta_{5} V E R+ \\
& \alpha_{1} M R R * A B S_{D A}(\text { or } D A)+\alpha_{2} V R R * A B S_{D A}(\text { or } D A)+\alpha_{3} M E R * \\
& A B S_{D A}(\text { or } D A)+\alpha_{4} V E R * A B S_{D A}(\text { or } D A)+\beta_{6} S I Z E+\beta_{7} Q U I C K+ \\
& \beta_{8} L E V+\beta_{9} N A R+\beta_{10} I N V E N+\beta_{11} L O S S+\beta_{12} T O P 8+ \\
& \beta_{13} N E W+\beta_{14} S P T+\beta_{15} A G E+\varepsilon
\end{aligned}
$$

Table 2 is provided to highlight the summary of the variables used in equation (3). 
Table 2: Variables and Definitions for Equation (3)

\begin{tabular}{|c|c|c|}
\hline Variables & Definition & $\begin{array}{l}\text { Types of } \\
\text { Variables }\end{array}$ \\
\hline MOPI & $\begin{array}{l}\text { A dummy variable that takes the value } \\
\text { of } 1 \text { if the firm receives a modified } \\
\text { audit opinion, } 0 \text { for otherwise }\end{array}$ & Dependent \\
\hline $\mathrm{MRR} * \mathrm{ABS}_{\mathrm{DA}}($ or DA) & $\begin{array}{l}\text { The interaction term for MMR and } \\
\mathrm{ABS}_{\mathrm{DA}} \text { (or positive/negative DA) }\end{array}$ & Independent \\
\hline $\mathrm{VRR}^{*} \mathrm{ABS}_{\mathrm{DA}}$ (or DA) & $\begin{array}{l}\text { The interaction term for VRR and } \\
\mathrm{ABS}_{\mathrm{DA}} \text { (or positive/ negative DA) }\end{array}$ & Independent \\
\hline $\mathrm{MER} * \mathrm{ABS}_{\mathrm{DA}}($ or $\mathrm{DA})$ & $\begin{array}{l}\text { the interaction term for MER and } \\
\mathrm{ABS}_{\mathrm{DA}} \text { (or positive/negative DA) }\end{array}$ & Independent \\
\hline $\mathrm{VER}^{*} \mathrm{ABS}_{\mathrm{DA}}$ (or DA) & $\begin{array}{l}\text { The interaction term for VER and } \\
\mathrm{ABS}_{\mathrm{DA}} \text { (or positive/negative DA) }\end{array}$ & Independent \\
\hline QUICK & $\begin{array}{l}\text { Quick assets including cash, short- } \\
\text { term investments, and accounts } \\
\text { receivable divided by total current } \\
\text { liabilities. }\end{array}$ & Control \\
\hline NAR & $\begin{array}{l}\text { Net account receivables divided by } \\
\text { total assets }\end{array}$ & Control \\
\hline INVEN & Net inventory divided by total assets & Control \\
\hline SIZE & Book to market value ratio & Control \\
\hline LEV & Debt to asset ratio & Control \\
\hline AGE & $\begin{array}{l}\text { Number of years since the } \\
\text { establishment }\end{array}$ & Control \\
\hline TOP8 & $\begin{array}{l}\text { A dummy variable that takes the value } \\
\text { of } 1 \text { if the auditor is one of the Top } 8 \\
\text { Audit firms in China, } 0 \text { otherwise }\end{array}$ & Control \\
\hline SPT & $\begin{array}{l}\text { A dummy variable that takes the value } \\
\text { of } 1 \text { if the firm is classified as a 'special } \\
\text { treatment firm', } 0 \text { for otherwise }\end{array}$ & Control \\
\hline LOSS & $\begin{array}{l}\text { A dummy variable that takes the value } \\
\text { of } 1 \text { if the firm reported a loss in the } \\
\text { previous year, } 0 \text { for otherwise }\end{array}$ & Control \\
\hline NEW & $\begin{array}{l}\text { A dummy variable that takes the value } \\
\text { of } 1 \text { if the firm conducts a seasoned } \\
\text { equity offering in the following year, } \\
0 \text { for otherwise. }\end{array}$ & Control \\
\hline
\end{tabular}




\section{Results}

\subsection{Descriptive Statistics}

Table 3 summarises the descriptive statistics of the pooled sample. Panel A breaks down the whole sample into RA and EA rotations, depending upon rotation status. For RA rotation, we identified 734 cases as MRR and 5,293 cases as VRR, respectively. Meanwhile, 7,829 observations were identified as continuous RA (i.e., without RA rotation). Regarding EA rotation, we identified 563 cases as MER, 6,010 cases as VER, and 7,283 cases as continuous EA. Overall, the frequencies of voluntary rotations (either VRR or VER) were much greater than those of mandatory

Table 3: Descriptive Statistics (Pooled Sample)

Panel $A$ - The relative frequency of auditor partner rotations depending on auditor types

\begin{tabular}{|c|c|c|}
\hline Review partner (RA) & $\mathrm{N}$ & $\%$ \\
\hline $\begin{array}{l}\text { Mandatory rotation of Review partner within the same } \\
\text { audit firm (MRR) }\end{array}$ & 734 & 5.3 \\
\hline $\begin{array}{l}\text { Voluntary rotation of Review partner within the same } \\
\text { audit firm (VRR) }\end{array}$ & 5,293 & 38.2 \\
\hline No rotation of Review partner (i.e., continuous RA) & 7,829 & 56.5 \\
\hline Total number of observations in the sample & 13,856 & 100.0 \\
\hline Engagement partner (EA) & $\mathrm{N}$ & $\%$ \\
\hline $\begin{array}{l}\text { Mandatory rotation of Engagement partner within the same } \\
\text { audit firm (MER) }\end{array}$ & 563 & 4.1 \\
\hline $\begin{array}{l}\text { Voluntary rotation of Engagement partner within the same } \\
\text { audit firm (VER) }\end{array}$ & 6,010 & 43.4 \\
\hline No rotation of Engagement partner (i.e., continuous EA) & 7,283 & 52.6 \\
\hline Total number of observations in the sample & 13,856 & 100.0 \\
\hline
\end{tabular}

Panel B - Descriptive statistics of test variables (pooled sample)

\begin{tabular}{lrrrrrr}
\hline & $\mathrm{N}$ & Mean & Std. Dev. & $\mathrm{p} 25$ & $\mathrm{p} 50$ & $\mathrm{p} 75$ \\
\hline ABS $_{\text {DA }}$ & 13,856 & 0.069 & 0.086 & 0.020 & 0.044 & 0.086 \\
Positive DA & 6,727 & 0.068 & 0.076 & 0.019 & 0.043 & 0.086 \\
Negative DA & 7,129 & -0.066 & 0.069 & -0.086 & -0.045 & -0.021 \\
MRR & 13,856 & 0.053 & 0.224 & 0.000 & 0.000 & 0.000 \\
VRR & 13,856 & 0.382 & 0.486 & 0.000 & 0.000 & 1.000 \\
MER & 13,856 & 0.041 & 0.197 & 0.000 & 0.000 & 0.000 \\
VER & 13,856 & 0.434 & 0.496 & 0.000 & 0.000 & 1.000 \\
\hline
\end{tabular}


Table 3: Continued

\begin{tabular}{lrrrrrr}
\hline & $\mathrm{N}$ & Mean & Std. Dev. & $\mathrm{p} 25$ & $\mathrm{p} 50$ & $\mathrm{p} 75$ \\
\hline SIZE & 13,856 & 21.890 & 1.272 & 21.010 & 21.760 & 22.620 \\
CFO & 13,856 & 0.051 & 0.095 & 0.002 & 0.049 & 0.102 \\
GRW & 13,856 & 0.045 & 0.386 & -0.034 & 0.098 & 0.214 \\
BM & 13,856 & 0.572 & 0.256 & 0.371 & 0.558 & 0.769 \\
LEV & 13,856 & 0.499 & 0.223 & 0.340 & 0.500 & 0.645 \\
AGE & 13,856 & 13.670 & 5.077 & 10.000 & 14.000 & 17.000 \\
TOP8 & 13,856 & 0.298 & 0.457 & 0.000 & 0.000 & 1.000 \\
FTEN & 13,856 & 4.983 & 2.759 & 3.000 & 4.000 & 6.000 \\
SOE & 13,856 & 0.049 & 0.215 & 0.000 & 0.000 & 0.000 \\
SPT & 13,856 & 0.039 & 0.194 & 0.000 & 0.000 & 0.000 \\
LOSS & 13,856 & 0.082 & 0.274 & 0.000 & 0.000 & 0.000 \\
NEW & 13,856 & 0.067 & 0.249 & 0.000 & 0.000 & 0.000 \\
PEIND & 13,856 & 0.365 & 0.051 & 0.333 & 0.333 & 0.385 \\
CONT & 13,856 & 0.371 & 0.155 & 0.246 & 0.354 & 0.488 \\
EMOT3 & 13,856 & 13.960 & 0.809 & 13.470 & 13.990 & 14.480 \\
\hline
\end{tabular}

Panel C - Descriptive statistics of three subgroups by review partner

\begin{tabular}{|c|c|c|c|c|c|c|c|c|c|c|}
\hline & \multicolumn{3}{|c|}{ MRR } & \multicolumn{3}{|c|}{ VRR } & \multicolumn{3}{|c|}{ Continuous RA } & \multirow{2}{*}{$\begin{array}{c}\mathrm{K}-\mathrm{W} \\
\text { test } \\
(p \text {-va- } \\
\text { lue })\end{array}$} \\
\hline & $\mathrm{N}$ & Mean & P50 & $\mathrm{N}$ & Mean & P50 & $\mathrm{N}$ & Mean & 50 & \\
\hline $\mathrm{ABS}_{\mathrm{DA}}$ & 734 & 0.076 & 0.047 & 5,293 & 0.070 & 0.043 & 7,829 & 68 & 0.045 & 0.248 \\
\hline Positive DA & 342 & 0.069 & 0.045 & 2,573 & 0.070 & 0.043 & 3,812 & 0.066 & 0.043 & 0.307 \\
\hline Negative DA & 392 & -0.074 & -0.049 & 2,720 & -0.064 & -0.043 & 4,017 & -0.066 & -0.046 & 0.128 \\
\hline SIZE & 734 & 22.053 & 21.940 & 5,293 & 21.776 & 21.642 & 7,829 & 21.947 & 21.813 & 0.000 \\
\hline $\mathrm{CFO}$ & 734 & 0.051 & 0.045 & 5,293 & 0.049 & 0.049 & 7,829 & 0.052 & 0.049 & 0.314 \\
\hline GRW & 734 & 0.020 & 0.084 & 5,293 & 0.052 & 0.103 & 7,829 & 0.044 & 0.097 & 0.005 \\
\hline $\mathrm{BM}$ & 734 & 0.614 & 0.618 & 5,293 & 0.568 & 0.552 & 7,829 & 0.572 & 0.555 & 0.000 \\
\hline LEV & 734 & 0.535 & 0.538 & 5,293 & 0.492 & 0.494 & 7,829 & 0.501 & 0.501 & 0.000 \\
\hline AGE & 734 & 15.386 & 15 & 5,293 & 13.010 & 13 & 7,829 & 13.954 & 14 & 0.000 \\
\hline TOP8 & 734 & & 0 & & & 0 & & & 0 & 0.000 \\
\hline FTEN & 734 & 6.402 & 6 & 5,293 & 4.661 & 4 & 7,829 & 5.067 & 4 & 0.000 \\
\hline SOE & 734 & 0.045 & 0 & 5,293 & 0.055 & 0 & 7,829 & 0.045 & 0 & 0.021 \\
\hline SPT & 734 & 0.040 & 0 & 5,293 & 0.039 & 0 & 7,829 & 0.040 & 0 & 0.996 \\
\hline LOSS & 734 & 0.110 & 0 & 5,293 & 0.070 & 0 & 7,829 & 0.087 & 0 & 0.000 \\
\hline NEW & 734 & 0.052 & 0 & 5,293 & 0.074 & 0 & 7,829 & 0.063 & 0 & 0.009 \\
\hline PEINL & 734 & 0.365 & 0.333 & 5,293 & 0.364 & 0.333 & 7,829 & 0.366 & 0.333 & 0.444 \\
\hline CONT & 734 & 0.351 & 0.316 & 5,293 & 0.377 & 0.360 & 7,829 & 0.370 & 0.353 & 0.000 \\
\hline EMOT3 & 734 & 14.002 & 14.027 & 5,293 & 13.898 & 13.923 & 7,829 & 13.999 & 14.033 & 0.000 \\
\hline
\end{tabular}


Table 3: Continued

Panel D - Descriptive statistics of three subgroups by engagement partner

\begin{tabular}{|c|c|c|c|c|c|c|c|c|c|c|}
\hline & \multicolumn{3}{|c|}{ MER } & \multicolumn{3}{|c|}{ VER } & \multicolumn{3}{|c|}{ Continuous EA } & \multirow{2}{*}{$\begin{array}{c}\text { K-W } \\
\text { test } \\
(p-v a \\
\text { lue })\end{array}$} \\
\hline & $\mathrm{N}$ & Mean & P50 & $\mathrm{N}$ & Mean & P50 & $\mathrm{N}$ & Mean & P50 & \\
\hline $\mathrm{ABS}_{\mathrm{DA}}$ & 563 & 0.068 & 0.040 & 6,010 & 71 & 0.044 & 7,283 & 0.068 & 0.044 & 40.519 \\
\hline Positive DA & 287 & 0.068 & 0.039 & 2,946 & 0.070 & 0.043 & 3,494 & 0.065 & 0.043 & 30.363 \\
\hline Negative DA & 276 & -0.064 & -0.041 & 3,064 & -0.066 & -0.044 & 3,789 & -0.066 & -0.046 & 0.884 \\
\hline SIZE & 563 & 22.015 & 21.920 & 6,010 & 21.800 & 21.661 & 7,283 & 21.950 & 21.813 & 0.000 \\
\hline $\mathrm{CFO}$ & 563 & 0.047 & 0.051 & 6,010 & 0.050 & 0.049 & 7,283 & 0.051 & 0.048 & 0.917 \\
\hline GRW & 563 & 0.030 & 0.079 & 6,010 & 0.052 & 0.104 & 7,283 & 0.041 & 0.096 & 0.001 \\
\hline $\mathrm{BM}$ & 563 & 0.602 & 0.607 & 6,010 & 0.565 & 0.545 & 7,283 & 0.577 & 0.565 & 0.000 \\
\hline LEV & 563 & 0.513 & 0.535 & 6,010 & 0.498 & 0.499 & 7,283 & 0.500 & 0.499 & 0.068 \\
\hline AGE & 563 & 14.734 & 15 & 6,010 & 13.221 & 13 & 7,283 & 13.957 & 14 & 0.000 \\
\hline TOP8 & 563 & 0.240 & 0 & 6,010 & 0.288 & 0 & 7,283 & 0.311 & 0 & 0.000 \\
\hline FTEN & 563 & 6.602 & 6 & 6,010 & 4.684 & 4 & 7,283 & 5.104 & 4 & 0.000 \\
\hline SOE & 563 & 0.044 & 0 & 6,010 & 0.053 & 0 & 7,283 & 0.046 & 0 & 0.154 \\
\hline SPT & 563 & 0.023 & 0 & 6,010 & 0.043 & 0 & 7,283 & 0.037 & 0 & 0.026 \\
\hline LOSS & 563 & 0.096 & 0 & 6,010 & 0.076 & 0 & 7,283 & 0.085 & 0 & 0.067 \\
\hline NEW & 563 & 0.073 & 0 & 6,010 & 0.074 & 0 & 7,283 & 0.060 & 0 & 0.003 \\
\hline PEIND & 563 & 0.363 & 0.333 & 6,010 & 0.365 & 0.333 & 7,283 & 0.366 & 0.333 & 0.368 \\
\hline CONT & 563 & 0.353 & 0.323 & 6,010 & 0.374 & 0.357 & 7,283 & 0.371 & 0.354 & 0.009 \\
\hline EMOT3 & 563 & 13.965 & 13.998 & 6,010 & 13.909 & 13.954 & 7,283 & 14.000 & 14.028 & 0.000 \\
\hline
\end{tabular}

Note: Bold characteristics represent statistical significance at less than $5 \%$.

rotations (either MRR or MER) in the sample. In addition, the frequency of MRR was greater than that of MER, while the frequency of VRR was less than that of VER.

Panel B of Table 3 presents the descriptive statistics of test variables for the first test model. All continuous variables are winsorized at the $1 \%$ and $99 \%$ percentiles. $\mathrm{ABS}_{\mathrm{DA}}$ has a mean of 0.069 and a median of 0.044 . Then, we split $\mathrm{ABS}_{\mathrm{DA}}$ into positive and negative DA groups. The positive DA group had a mean of 0.068 and a median of 0.043 , and the negative DA group had a mean of -0.066 and a median of -0.045 . The means of MRR and VRR were 0.053 and 0.382, while the means of MER and VER were 0.041 and 0.434 , suggesting that the voluntary rotation of auditor occurred more frequently compared with the mandatory rotation in the sample. Both the mean and median of firm size (SIZE) were over 21. Meanwhile, those of CFO were around 0.05, implying the majority of 
sampled firms had positive cash flow from operations. Average firm age (AGE) was almost 13 years, and the average audit firm tenure (FTEN) was over 4 years.

Panels C and D provide descriptive statistics for both RA and EA subgroups with Kruskal-Wallis test results. In general, the results from both Panels $C$ and D showed a similar trend. We did not find any significant difference across the subgroups in terms of $\mathrm{ABS}_{\mathrm{DA}}$, Positive DA, or Negative DA. However, we captured some significant differences in terms of firm size (SIZE), growth (GRW), book-to-market ratio $(B M)$, leverage $(L E V)$, firm age (AGE), Top 8 audit firms (TOP8), audit firm tenure (FTEN), seasoned equity offering (NEW), controlling shareholder's ownership percentage (CONT), and TOP 3 management emoluments (EMOT3).

For the sake of further analysis, we conducted a series of pairwise mean comparisons across the subgroups, with the results presented in Table 4. Due to the unequal variance across subgroups, we applied the Games-Howell test rather than Turkey's test. In Panel A, we did not find a significant difference in terms of $\mathrm{ABS}_{\mathrm{DA}}$, Positive DA or Negative DA. However, the results showed that VRR group had a significantly smaller mean of firm size (SIZE) compared with continuous RA and MRR groups. Conversely, VRR group had higher ownership concentration (CONT) across the three subgroups. In short, the smaller firms with concentrated ownership experience more frequently VRR. By contrast, the results also indicated that MRR group had greater means of $B M$, $L E V, A G E$ and FTEN compared with continuous RA and VRR groups, implying that MRR group presents higher book-to-market ratios, higher leverage, longer firm age, and longer audit firm tenures among the three subgroups. Conversely, the MRR group had the lowest mean of TOP8 and CONT compared with continuous RA and VRR groups, suggesting that MRR was more likely to occur within non-TOP8 audit firms, and had a lower ownership concentration by the controlling shareholder. Panel B of Table 4 showed the pairwise comparisons of means according to EA with its rotation status. Overall, the trends are similar to those in Panel A.

Table 5 presents a Pearson correlation matrix of test variables in the first regression model, along with their significance. There were positive correlations between $\mathrm{ABS}_{\mathrm{DA}}$, MRR and VER. As for the control variables, SIZE, CFO and BM were negatively correlated with $\mathrm{ABS}_{\mathrm{DA}}$ indicating that the larger firms and firms with a higher operating cash level and a greater book-to-market ratio had lower levels of $\mathrm{ABS}_{\mathrm{DA}}$. In addition, 
Table 4: Pairwise Comparison of Means across Subgroups by Auditor Types and Rotation Status

Panel A-Pairwise comparison of means by review audit partner (RA)

\begin{tabular}{|c|c|c|c|c|c|c|}
\hline & \multicolumn{2}{|c|}{ MRR vs. Continuous RA } & \multicolumn{2}{|c|}{ VRR vs. Continuous RA } & \multicolumn{2}{|c|}{ VRR vs. MRR } \\
\hline & t-stat & $\underset{p \text {-value }}{\text { adj. }}$ & t-stat & $\begin{array}{c}\text { adj. } \\
p \text {-value }\end{array}$ & t-stat & $\begin{array}{c}\text { adj. } \\
p \text {-value }\end{array}$ \\
\hline $\mathrm{ABS}_{\mathrm{DA}}$ & 1.91 & 0.137 & 0.87 & 0.662 & -1.52 & 0.280 \\
\hline Positive DA & 0.67 & 0.783 & 2.12 & 0.086 & 0.32 & 0.944 \\
\hline Negative DA & -1.74 & 0.193 & 1.22 & 0.440 & 2.19 & 0.075 \\
\hline SIZE & 2.12 & 0.087 & -7.66 & -0.000 & -5.48 & 0.000 \\
\hline $\mathrm{CFO}$ & -0.15 & 0.987 & -1.60 & 0.248 & -0.57 & 0.834 \\
\hline GRW & -1.43 & 0.326 & 1.16 & 0.478 & 1.87 & 0.147 \\
\hline BM & 4.19 & 0.000 & -0.85 & 0.672 & -4.48 & 0.000 \\
\hline LEV & 3.80 & 0.000 & -2.47 & 0.036 & -4.83 & 0.000 \\
\hline AGE & 8.35 & 0.000 & -10.41 & -0.000 & -13.46 & 0.000 \\
\hline TOP8 & -4.13 & 0.000 & -1.75 & 0.185 & 3.20 & 0.004 \\
\hline FTEN & 12.51 & 0.000 & -8.46 & -0.000 & -16.10 & 0.000 \\
\hline SOE & 0.03 & 0.999 & 2.67 & 0.021 & 1.23 & 0.433 \\
\hline SPT & 0.06 & 0.998 & -0.05 & 0.999 & -0.08 & 0.997 \\
\hline LOSS & 1.91 & 0.135 & -3.77 & 0.000 & -3.38 & 0.002 \\
\hline NEW & -1.28 & 0.405 & 2.52 & 0.032 & 2.51 & 0.032 \\
\hline PEIND & -0.37 & 0.927 & -1.52 & 0.283 & -0.30 & 0.951 \\
\hline CONT & -3.05 & 0.007 & 2.50 & 0.033 & 4.11 & 0.000 \\
\hline EMOT3 & 0.09 & 0.996 & -7.06 & -0.000 & -3.18 & 0.004 \\
\hline
\end{tabular}

Panel B - Pairwise comparison of means by engagement audit partner (EA)

\begin{tabular}{|c|c|c|c|c|c|c|}
\hline & \multicolumn{2}{|c|}{ MER vs. Continuous EA } & \multicolumn{2}{|c|}{ VER vs. Continuous EA } & \multicolumn{2}{|c|}{ VER vs. MER } \\
\hline & t-stat & $\begin{array}{c}\text { adj. } \\
p \text {-value }\end{array}$ & t-stat & $\underset{p \text {-value }}{\text { adj. }}$ & t-stat & $\underset{p \text {-value }}{\text { adj. }}$ \\
\hline $\mathrm{ABS}_{\mathrm{DA}}$ & 0.08 & 0.996 & 1.97 & 0.120 & 0.70 & 0.765 \\
\hline Positive DA & 0.57 & 0.835 & 2.69 & 0.020 & 0.46 & 0.889 \\
\hline Negative DA & 0.50 & 0.873 & 0.01 & 1.000 & -0.49 & 0.877 \\
\hline SIZE & 1.29 & 0.401 & -6.76 & -0.000 & -4.23 & 0.000 \\
\hline $\mathrm{CFO}$ & -1.04 & 0.552 & -0.72 & 0.749 & 0.74 & 0.737 \\
\hline GRW & -0.75 & 0.735 & 1.50 & 0.293 & 1.37 & 0.357 \\
\hline $\mathrm{BM}$ & 2.22 & 0.068 & -2.72 & 0.018 & -3.26 & 0.003 \\
\hline LEV & 1.49 & 0.295 & -0.47 & 0.888 & -1.68 & 0.212 \\
\hline AGE & 3.80 & 0.000 & -8.33 & -0.000 & -7.33 & -0.000 \\
\hline TOP8 & -3.78 & 0.001 & -2.93 & 0.010 & 2.52 & 0.032 \\
\hline FTEN & 12.42 & -0.000 & -8.88 & 0.000 & -15.87 & -0.000 \\
\hline SOE & -0.15 & 0.988 & 1.86 & 0.152 & 0.91 & 0.634 \\
\hline SPT & -2.06 & 0.098 & 1.80 & 0.171 & 2.92 & 0.010 \\
\hline LOSS & 0.82 & 0.692 & -1.98 & 0.118 & -1.54 & 0.272 \\
\hline NEW & 1.16 & 0.479 & 3.35 & 0.002 & 0.14 & 0.990 \\
\hline PEIND & -1.25 & 0.427 & -0.67 & 0.778 & 0.97 & 0.596 \\
\hline CONT & -2.67 & 0.021 & 1.17 & 0.470 & 3.11 & 0.005 \\
\hline EMOT3 & -1.07 & 0.532 & -6.66 & -0.000 & -1.58 & 0.255 \\
\hline
\end{tabular}


TOP8, and EMOT3 also had negative correlation coefficients with $\mathrm{ABS}_{\mathrm{DA}}$, implying that firms with non-TOP 8 auditors and greater emoluments for top 3 management had smaller levels of $\mathrm{ABS}_{\mathrm{DA}}$. By contrast, $L E V$, $A G E, S P T, L O S S$ and PEIND were positively correlated with $\mathrm{ABS}_{\mathrm{DA}}$, implying a highly leveraged firm, an older firm, a special treatment firm, a loss reporting-firm, and the firm with a higher ratio of independent directors in the board was likely to move together with the level of $A B S_{D A}$. As expected, the correlations between MRR and VRR, and MER and VER showed negative signs. However, MRR was positively correlated with both MER, indicating that MRR often accompanies MER. On the other hand, VRR was positively correlated with VER, but negatively with MER, showing that VRR coincides more frequently with VER, but less frequently with MER.

SIZE was positively correlated with MRR and MER, but negatively with VRR and VER, indicating that a larger firm experiences more frequent mandatory rotations of audit partners (i.e., MRR and/or MER), while smaller firms were more likely to experience voluntary rotations of audit partners (i.e., VRR and/or VER). Similar trends were found with $B M, A G E$ and FTEN, indicating that older firms and those firms with a higher leverage ratio and longer audit firm tenures were positively correlated with the mandatory rotation of auditors, but negatively with voluntary rotation. The TOP 8 audit firms were less likely to experience auditor rotation. If the controlling shareholders were SOE (SOE), then the firms were experiencing more frequent VRR. Special treatment firms $(S P T)$ were negatively correlated with MER, but positively with VER. Meanwhile, NEW (seasoned equity offering in year $t+1$ ) was positively correlated with VRR and VER. The ownership percentage of controlling shareholder (CONT) had negative correlation coefficients with MRR and MER, but positive coefficient with VRR, suggesting that a firm with higher ownership concentration experienced more frequent VRR, but less frequent mandatory rotation of auditors.

Table 6 shows the regression results of the first test model. Inspired by the fact that the sample was constructed from a panel data set, we attempted a panel data analysis. We compared the fixed effect (FE) model and random effect (RE) model, yet the Hausman test results supported an FE approach in all test models. ${ }^{5}$ Thus, Table 6 presents the

\footnotetext{
${ }^{5}$ For example, the model (2) in panel A, the Hausman test result returns Chi-2 of 148.64 $(\mathrm{p}<0.000)$, indicating that RE estimators are inconsistent.
} 


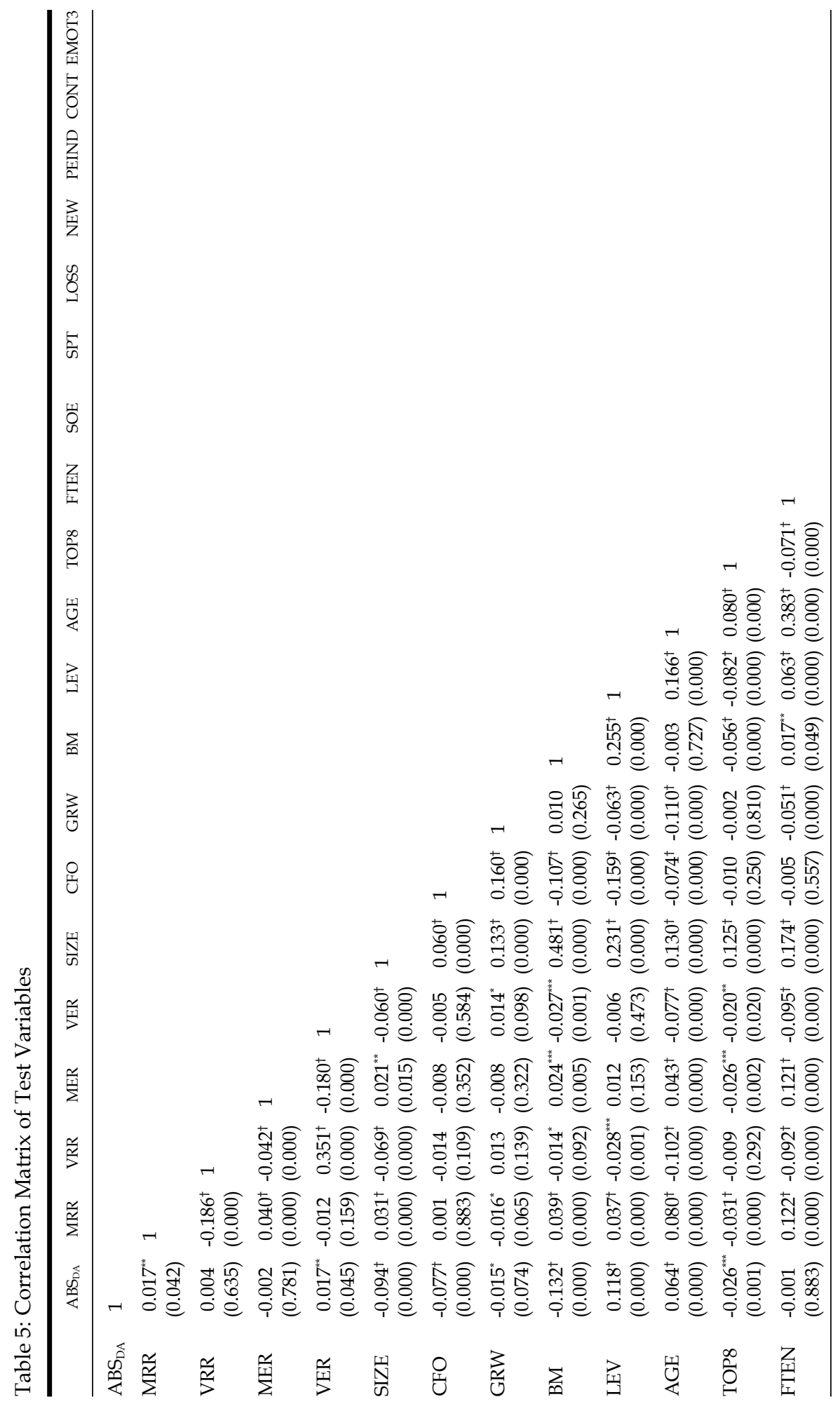




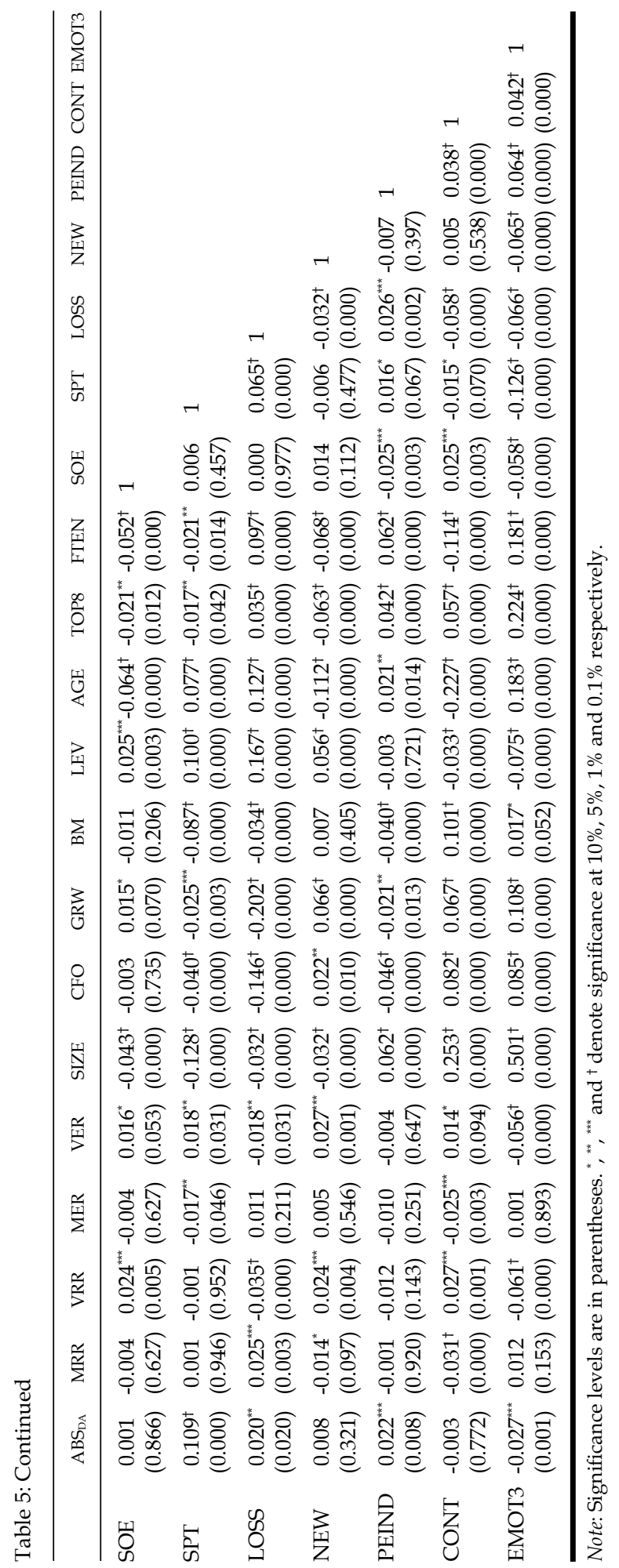


Table 6: Effects of Audit Partner Rotation on DA

\begin{tabular}{|c|c|c|c|}
\hline & Panel A - $\mathrm{ABS}_{\mathrm{DA}}$ & Panel B - Positive DA & Panel C - Negative DA \\
\hline Dep. Var. & (1) $\mathrm{ABS}_{\mathrm{DA}}$ & (2) $\mathrm{DA}>0$ & (3) $\mathrm{DA}<0$ \\
\hline MRR & $\begin{array}{l}0.006^{\star *} \\
(2.021)\end{array}$ & $\begin{array}{c}0.002 \\
(0.667)\end{array}$ & $\begin{array}{l}-0.006^{* *} \\
(-2.075)\end{array}$ \\
\hline VRR & $\begin{array}{c}0.000 \\
(0.089)\end{array}$ & $\begin{array}{c}0.001 \\
(0.677)\end{array}$ & $\begin{array}{c}-0.001 \\
(-0.742)\end{array}$ \\
\hline MER & $\begin{array}{c}0.001 \\
(0.234)\end{array}$ & $\begin{array}{c}0.005 \\
(1.358)\end{array}$ & $\begin{array}{c}-0.001 \\
(-0.307)\end{array}$ \\
\hline VER & $\begin{array}{c}0.001 \\
(0.515)\end{array}$ & $\begin{array}{c}0.003^{*} \\
(1.715)\end{array}$ & $\begin{array}{c}0.001 \\
(0.974)\end{array}$ \\
\hline SIZE & $\begin{array}{c}0.001 \\
(0.659)\end{array}$ & $\begin{array}{l}0.007^{* * *} \\
(3.003)\end{array}$ & $\begin{array}{c}0.012^{\dagger} \\
(5.552)\end{array}$ \\
\hline $\mathrm{CFO}$ & $\begin{array}{c}-0.034^{\dagger} \\
(-3.748)\end{array}$ & $\begin{array}{r}-0.658^{\dagger} \\
(-54.580)\end{array}$ & $\begin{array}{r}-0.603^{\dagger} \\
(-54.640)\end{array}$ \\
\hline GRW & $\begin{array}{c}0.009^{\dagger} \\
(4.305)\end{array}$ & $\begin{array}{r}0.023^{\dagger} \\
(11.060)\end{array}$ & $\begin{array}{r}0.023^{\dagger} \\
(11.450)\end{array}$ \\
\hline $\mathrm{BM}$ & $\begin{array}{c}-0.046^{\dagger} \\
(-7.454)\end{array}$ & $\begin{array}{c}-0.058^{\dagger} \\
(-8.619)\end{array}$ & $\begin{array}{l}-0.014^{* *} \\
(-2.296)\end{array}$ \\
\hline LEV & $\begin{array}{r}0.036^{\dagger} \\
(5.822)\end{array}$ & $\begin{array}{c}-0.003 \\
(-0.509)\end{array}$ & $\begin{array}{r}-0.070^{\dagger} \\
(-11.000)\end{array}$ \\
\hline AGE & $\begin{array}{c}-0.002 \\
(-0.590)\end{array}$ & $\begin{array}{c}0.003 \\
(1.134)\end{array}$ & $\begin{array}{c}-0.001 \\
(-0.301)\end{array}$ \\
\hline TOP8 & $\begin{array}{c}-0.002 \\
(-0.881)\end{array}$ & $\begin{array}{c}-0.000 \\
(-0.151)\end{array}$ & $\begin{array}{c}0.001 \\
(0.507)\end{array}$ \\
\hline FTEN & $\begin{array}{c}0.000 \\
(0.828)\end{array}$ & $\begin{array}{c}0.000 \\
(0.931)\end{array}$ & $\begin{array}{c}-0.000 \\
(-0.037)\end{array}$ \\
\hline SOE & $\begin{array}{c}-0.004 \\
(-0.861)\end{array}$ & $\begin{array}{c}0.000 \\
(0.090)\end{array}$ & $\begin{array}{c}0.008^{*} \\
(1.746)\end{array}$ \\
\hline SPT & $\begin{array}{r}0.024^{\dagger} \\
(6.011)\end{array}$ & $\begin{array}{r}0.013^{\dagger} \\
(3.329)\end{array}$ & $\begin{array}{c}0.005 \\
(1.225)\end{array}$ \\
\hline LOSS & $\begin{array}{c}0.002 \\
(0.560)\end{array}$ & $\begin{array}{l}-0.007^{* *} \\
(-2.424)\end{array}$ & $\begin{array}{c}-0.017^{\dagger} \\
(-5.534)\end{array}$ \\
\hline NEW & $\begin{array}{c}-0.001 \\
(-0.229)\end{array}$ & $\begin{array}{c}0.004 \\
(1.386)\end{array}$ & $\begin{array}{l}0.006^{* *} \\
(2.304)\end{array}$ \\
\hline PEIND & $\begin{array}{c}-0.021 \\
(-1.043)\end{array}$ & $\begin{array}{c}-0.007 \\
(-0.302)\end{array}$ & $\begin{array}{c}0.011 \\
(0.593)\end{array}$ \\
\hline CONT & $\begin{array}{r}0.049^{\dagger} \\
(4.350)\end{array}$ & $\begin{array}{c}0.019 \\
(1.542)\end{array}$ & $\begin{array}{c}-0.011 \\
(-0.972)\end{array}$ \\
\hline
\end{tabular}


Table 6: Continued

\begin{tabular}{|c|c|c|c|}
\hline & Panel A - ABS ${ }_{D A}$ & Panel B - Positive DA & Panel C - Negative DA \\
\hline Dep. Var. & (1) $\mathrm{ABS}_{\mathrm{DA}}$ & (2) $\mathrm{DA}>0$ & (3) $\mathrm{DA}<0$ \\
\hline EMOT3 & $\begin{array}{c}-0.004^{*} \\
(-1.806)\end{array}$ & $\begin{array}{c}-0.002 \\
(-0.952)\end{array}$ & $\begin{array}{c}0.002 \\
(1.040)\end{array}$ \\
\hline Constant & $\begin{array}{c}0.093^{*} \\
(1.669)\end{array}$ & $\begin{array}{c}-0.059 \\
(-1.022)\end{array}$ & $\begin{array}{r}-0.280^{\dagger} \\
(-5.008)\end{array}$ \\
\hline Year & Controlled & Controlled & Controlled \\
\hline $\mathrm{N}$ & 13,856 & 6,727 & 7,129 \\
\hline Adj. - $\mathrm{R}^{2}$ & 0.2000 & 0.5063 & 0.4953 \\
\hline $\begin{array}{l}\text { F-test } \\
\text { (Prob.>F) }\end{array}$ & $\begin{array}{c}12.39 \\
(0.000)\end{array}$ & $\begin{array}{l}103.30 \\
(0.000)\end{array}$ & $\begin{array}{l}109.30 \\
(0.000)\end{array}$ \\
\hline
\end{tabular}

Note: $t$-statistics are in parentheses. ${ }^{*}, * * * * *$ and ${ }^{\dagger}$ denote significance at $10 \%, 5 \%, 1 \%$ and $0.1 \%$ respectively.

FE results primarily, given that OLS results are qualitatively similar to FE results.

In Panel A of Table 6, MRR was positively associated with $\mathrm{ABS}_{\mathrm{DA}}$, indicating that MRR was more likely to increase the level of $A_{B B} S_{D A}$, thereby deteriorating audit quality. This implied that a mandatorily rotated RA was more likely to be lenient about the firm's accounting irregularities, possibly because he/she had an incentive to retain the existing client during subsequent periods. Therefore, $\mathrm{H}_{1}$ was partially accepted in the MRR case. Turning to control variables, GRW, LEV, $S P T$ and CONT were significantly positively associated with $\mathrm{ABS}_{\mathrm{DA}}$, indicating that a firm with higher sales growth, a higher leverage ratio, a higher concentration ratio by controlling shareholder, as well as special treatment firms were more likely to increase $\mathrm{ABS}_{\mathrm{DA}}$. On the other hand, $C F O$ and $B M$ were negatively associated with $\mathrm{ABS}_{\mathrm{DA}}$, implying that a Chinese firm with a higher cash level and a higher book-to-market ratio was less likely to create $\mathrm{ABS}_{\mathrm{DA}}$. Other control variables were showing no specific association with $\mathrm{ABS}_{\mathrm{DA}}$.

For an in-depth analysis, we split the total sample into positive DA and negative DA samples in Panels B and C, respectively. We failed to find any significant association between Positive DA and other types of partner rotations in Panel B, while there was a negative association between Negative DA and MRR (i.e., MRR is likely to increase the magnitude of downward DA). That is to say, RAs were more likely 
to acquiesce to downward DA rather than upward DA when they are mandatorily rotated. Therefore, $\mathrm{H}_{2}$ was partially accepted in MRR with negative DA sample. In short, MRR was positively associated with $\mathrm{ABS}_{\mathrm{DA}}$, and this association is more pronounced in negative DA group. This is possibly because the negative DA case was associated with lower costs of compromising audit quality, thereby providing more discretion to RAs, compared with positive DA case. ${ }^{6}$

Table 7 presents the results of the logit model. We employed MOPI as the dependent variable while and $\mathrm{ABS}_{\mathrm{DA}}$, positive $\mathrm{DA}$, and negative DA are adopted as the independent variables in Panels A, B and C, respectively.

In model (1) of Panel $\mathrm{A}, \mathrm{ABS}_{\mathrm{DA}}$ exhibited a positive association with MOPI, indicating that the higher $A B S_{D A}$ the more frequently auditors expressed MOPI, consistent with our expectations. In model (2), we created four interactions by combining auditor types and rotation statuses in order to examine the moderating effects of audit partner rotation. On the one hand, $M R R * A B S_{D A}$ and $V R R * A B S_{D A}$ presented no significant moderating effects. On the other hand, both MER and VER positively moderated the association between $\mathrm{ABS}_{\mathrm{DA}}$ and MOPI $\left(M E R * A B S_{D A}\right.$ and $\left.V E R * A B S_{D A}\right)$, suggesting that EAs were more likely to issue MOPI as $\mathrm{ABS}_{\mathrm{DA}}$ increases, regardless of whether the EAs were mandatorily or voluntarily rotated. These results are consistent with the previous findings, such as those made by Wang, Yu and Zhao (2015), in which the experience and qualifications of an EA are more crucial than those of an RA in terms of audit quality. This is also consistent with our expectation that an EA has less incentive to secure client-specific quasirent compared with RA.

Then, we further investigated the moderating effects of auditor rotation under positive and negative DA situations in Panel B and C. In model (3) of Panel B, positive DA was positively associated with MOPI, indicating that auditors were more likely to issue MOPI as upward DA increases. Nonetheless, we did not find any significant moderating effect on auditor rotations in model (4). Thus, we concluded that audit partner rotation had no significant moderating effect on the association between MOPI and positive DA.

\footnotetext{
${ }^{6}$ Although no table is provided here, we also split the total sample into six subgroups (two types of auditor times three rotation status) and rerun the regression test models in OLS to find the coefficients differences in test variables in each paired group. However, the results show that there is no significant differences between coefficients of test variables, confirming that auditor rotation has a limited impact on audit quality.
} 
Table 7: Moderating Effects of Audit Partner Rotation on the Association between Modified Audit Opinion and DA

\begin{tabular}{|c|c|c|c|c|c|c|}
\hline \multirow[b]{2}{*}{ Dep. Var. } & \multicolumn{2}{|c|}{ Panel A - $\mathrm{ABS}_{\mathrm{DA}}$} & \multicolumn{2}{|c|}{ Panel B - Positive DA } & \multicolumn{2}{|c|}{ Panel C - Negative DA } \\
\hline & (1) MOPI & (2) MOPI & (3) MOPI & (4) MOPI & (5) MOPI & (6) MOPI \\
\hline $\mathrm{ABS}_{\mathrm{DA}}$ & $\begin{array}{r}1.304^{\dagger} \\
(0.000)\end{array}$ & $\begin{array}{c}0.708 \\
(0.213)\end{array}$ & & & & \\
\hline $\begin{array}{l}\text { Positive (or } \\
\text { Negative) DA }\end{array}$ & & & $\begin{array}{l}1.500^{* *} \\
(0.022)\end{array}$ & $\begin{array}{c}0.709 \\
(0.478)\end{array}$ & $\begin{array}{l}-1.665^{* *} \\
(0.020)\end{array}$ & $\begin{array}{l}-1.089 \\
(0.330)\end{array}$ \\
\hline MRR & $\begin{array}{c}0.268 \\
(0.116)\end{array}$ & $\begin{array}{l}0.437^{* *} \\
(0.044)\end{array}$ & $\begin{array}{c}0.253 \\
(0.289)\end{array}$ & $\begin{array}{l}0.604^{* *} \\
(0.057)\end{array}$ & $\begin{array}{c}0.276 \\
(0.272)\end{array}$ & $\begin{array}{c}0.405 \\
(0.243)\end{array}$ \\
\hline VRR & $\begin{array}{l}-0.051 \\
(0.587)\end{array}$ & $\begin{array}{c}0.029 \\
(0.806)\end{array}$ & $\begin{array}{l}-0.217^{*} \\
(0.096)\end{array}$ & $\begin{array}{l}-0.273 \\
(0.121)\end{array}$ & $\begin{array}{c}0.135 \\
(0.338)\end{array}$ & $\begin{array}{l}0.446^{* *} \\
(0.021)\end{array}$ \\
\hline MER & $\begin{array}{l}-0.221 \\
(0.338)\end{array}$ & $\begin{array}{l}-0.577^{* *} \\
(0.048)\end{array}$ & $\begin{array}{c}0.023 \\
(0.937)\end{array}$ & $\begin{array}{l}-0.308 \\
(0.443)\end{array}$ & $\begin{array}{l}-0.560 \\
(0.145)\end{array}$ & $\begin{array}{l}-1.331^{* *} \\
(0.014)\end{array}$ \\
\hline VER & $\begin{array}{c}0.025 \\
(0.787)\end{array}$ & $\begin{array}{l}-0.140 \\
(0.235)\end{array}$ & $\begin{array}{c}0.022 \\
(0.860)\end{array}$ & $\begin{array}{l}-0.075 \\
(0.659)\end{array}$ & $\begin{array}{l}0.018 \\
(0.894)\end{array}$ & $\begin{array}{l}-0.308 \\
(0.103)\end{array}$ \\
\hline $\mathrm{MRR} * \mathrm{ABS}_{\mathrm{DA}}$ & & $\begin{array}{l}-2.263 \\
(0.171)\end{array}$ & & & & \\
\hline $\mathrm{VRR} * \mathrm{ABS}_{\mathrm{DA}}$ & & $\begin{array}{l}-1.035 \\
(0.222)\end{array}$ & & & & \\
\hline $\mathrm{MER}^{*} \mathrm{ABS}_{\mathrm{DA}}$ & & $\begin{array}{l}3.837^{* *} \\
(0.017)\end{array}$ & & & & \\
\hline $\mathrm{VER} * \mathrm{ABS}_{\mathrm{DA}}$ & & $\begin{array}{l}1.940^{* *} \\
(0.022)\end{array}$ & & & & \\
\hline $\begin{array}{l}\text { MRR Positive (or } \\
\text { Negative) DA }\end{array}$ & & & & $\begin{array}{l}-4.765 \\
(0.124)\end{array}$ & & $\begin{array}{c}2.144 \\
(0.429)\end{array}$ \\
\hline $\begin{array}{l}\text { VRR*Positive (or } \\
\text { Negative) DA }\end{array}$ & & & & $\begin{array}{c}0.551 \\
(0.709)\end{array}$ & & $\begin{array}{l}3.785^{\star *} \\
(0.017)\end{array}$ \\
\hline $\begin{array}{l}\text { MER } * \text { Positive (or } \\
\text { Negative) DA }\end{array}$ & & & & $\begin{array}{l}3.870 \\
(0.190)\end{array}$ & & $\begin{array}{l}-8.125^{\star *} \\
(0.013)\end{array}$ \\
\hline $\begin{array}{l}\text { VER } * \text { Positive (or } \\
\text { Negative) DA }\end{array}$ & & & & $\begin{array}{l}1.245 \\
(0.396)\end{array}$ & & $\begin{array}{l}-3.899^{* *} \\
(0.012)\end{array}$ \\
\hline Control Variables & Included & Included & Included & Included & Included & Included \\
\hline Year \& Industry & Controlled & Controlled & Controlled & Controlled & Controlled & Controlled \\
\hline $\mathrm{N}$ & 16,893 & 16,893 & 8,232 & 8,232 & 8,661 & 8,661 \\
\hline Pseudo $r^{2}$ & 0.362 & 0.363 & 0.346 & 0.347 & 0.398 & 0.401 \\
\hline Chi-2 & 2,712 & 2,721 & 1,330 & 1,336 & 1,446 & 1,458 \\
\hline$($ Prob. $>0)$ & $(0.000)$ & $(0.000)$ & $(0.000)$ & $(0.000)$ & $(0.000)$ & $(0.000)$ \\
\hline
\end{tabular}

Note: $p$-values are in parentheses. ${ }^{*}{ }^{* *},{ }^{* * *}$ and ${ }^{\dagger}$ denote significance at $10 \%, 5 \%, 1 \%$, and $0.1 \%$ respectively. Bold characteristics represent statistical significance of variables of interest at less than $5 \%$. 
Panel C of Table 7 offers the findings pertaining to the negative DA group and MOPI. In model (5), the level of DA was negatively associated with MOPI, as expected (i.e., the propensity of issuing MOPI increases as the magnitude of downward DA becomes greater). In model (6), VRR positively moderated the association between negative DA and MOPI (i.e., VRR $*$ Negative DA), while both MER and VER were negatively moderated (i.e., MER*Negative DA and VER*Negative DA). That is, in the first year of audit engagement, VRR was less likely to issue MOPI, while EAs were more likely to issue MOPI as the magnitude of downward DA increases.

In summary, we argued that these differences were primarily driven by the different roles and influences served and imposed by audit partners within Chinese audit firms. RAs tend to weigh up the costs and benefits of compromising audit quality compared with EAs. In the Chinese context, upward DA is likely to involve a higher risk of detection by regulators (Cheng et al., 2010; Kim et al., 2004). Adversely, downward DA may draw less attention from regulators, thereby allowing more discretion to RAs (Badertscher et al., 2009). Consequently, RAs are less likely to issue a MOPI when the magnitude of negative DA increases, but EAs are more likely to issue a MOPI as the magnitude of DA increases, regardless of whether it is positive or negative. Therefore, $\mathrm{H}_{3}$ was partially accepted in VRR with $\mathrm{ABS}_{\mathrm{DA}}$ and negative DA samples.

\section{Discussion and Conclusion}

We examined the effects of RA and EA rotation on audit quality, particularly when auditors were rotated within the same audit firm. It is well documented through previous studies that EAs and their levels of audit experience have a clear influence on the audit quality, while little has been discerned about the influences of RAs on audit quality. However, behavioural evidence suggests that a significant level of obedience pressure exists in Chinese audit firms. Thus, we posit that RAs may have a greater incentive to retain the existing client, and their incentive may affect overall audit quality.

We found that RAs were more likely to behave opportunistically to retain clients by weighing up the benefits and costs of compromising audit quality in the first year following a rotation. Using the Chinese data from both signing auditors, it was possible to analyze the effects of RA and EA rotation on audit quality, separately. The results indicated that MRR was positively associated with $\mathrm{ABS}_{\mathrm{DA}}$, implying that RAs 
may have an incentive to acquiesce the clients' accounting irregularities in their first year of audit engagement when they were mandatorily rotated. We also found that this relationship was more pronounced in negative DA group rather than positive DA group. As expected, EA rotation did not affect the level of $\mathrm{ABS}_{\mathrm{DA}}$, nor positive or negative $\mathrm{DA}$, suggesting that EAs were less affected by the auditor-client relationship as compared with RAs.

In addition, we examined whether or not the two types of audit partners behave opportunistically under a given DA level when issuing MOPI. Our findings showed that EAs were more likely to issue MOPI as the magnitude of DA increases, regardless of whether it was positive or negative. By contrast, VRR positively moderated the association between MOPI and negative DA, suggesting that voluntarily rotated RAs were less likely to issue MOPI although the magnitude of negative DA increases, a behaviour opposite to that displayed by EAs. This may be because negative DA associates with lower risks of audit failure compared with a positive DA generally, thereby providing more discretionary power to RAs. Nevertheless, we did not find any significant moderating effects of MRR on the association between DA and MOPI. This study demonstrates that RAs can bear an effect on audit quality by comparing the benefits and costs of compromising audit quality. Therefore, the relative roles and influences of RAs and EAs, which used to be largely ignored or underestimated in the previous studies, should be carefully examined in full view of the Chinese context.

Our research findings are different from previous studies which have documented a significant relationship between EA's characteristics and audit quality (e.g. Lennox et al., 2014; Wang, Yu, \& Zhao, 2015). They implicitly posit that EA's characteristics are the key factors influencing audit quality, while the RA's incentive in audit procedure can be ignored. However, as shown in numerous studies (e.g. DeZoort \& Lord, 1994; Brink et al., 2016; Liu, 2017; Zhao et al., 2020), RAs are also important key players in audit work. This study demonstrates how the relative influence of RAs and EAs can affect audit quality when they rotate, which has been hardly addressed in previous studies.

The findings of our study can help Chinese authorities, listed firms and academics gain more understanding about the relationship between audit quality and mandatory audit partner rotation. We provide new evidence that RAs are under bigger pressure to secure the subsequent audit when they rotate. The results in this study imply that the implementation of dual auditorship with equally-shared legal responsibility 
should be closely examined. If RAs' influence is greater than EAs', Chinese authorities could implement an effective monitoring system to restrain the roles of RAs in audit work.

The findings in this study urge caution for academic researchers as well. Previous empirical evidence document that EA's attributes have an impact on audit quality without proper consideration of the hierarchical dynamics within an audit firm. The two signing auditors (i.e., EAs and RAs) may have different incentives in audit work depending on their roles. Simply, the provision of equally shared legal responsibility for audit failure does not mean that they would affect audit quality equally. The findings in this study necessitate combining the findings in behavioural research with empirical research to understand the hierarchical dynamics between RAs and EAs.

Despite the findings, this study has limitations in several aspects. First, our study adopts the performance-adjusted discretionary accruals (Kothari et al., 2005) as a proxy for audit quality. However, there can be a measurement error in estimating discretionary accruals (e.g. Manry et al., 2008; Chen et al., 2008). Second, we focus on the auditor rotation and exclude the case of audit firm rotation. Since the audit quality can be affected by various factors, audit firm rotation can also affect audit quality (e.g. Chi \& Huang, 2005; Carey \& Simnett, 2006; Manry et al., 2008; Litt et al., 2014; Cameran et al., 2015). Third, although we tested the relative effects of RAs and EAs in audit work, we did not examine the effect of RAs' characteristics such as their professional experience, educational background, and years of service (Wang, Yu, \& Zhao, 2015). Audit quality can be also affected by RAs' characteristics.

\section{References}

Badertscher, B.A., Phillips, J.D., Pincus, M., \& Rego, S.O. (2009). Evidence on motivations for downward earnings management (Working paper). https:// papers.ssrn.com/sol3/papers.cfm?abstract_id $=921422$

Brink, A.G., Tang, F., \& Yang, L. (2016). The impact of estimate source and social pressure on auditors' fair value estimate choices. Behavioral Research in Accounting, 28(2), 29-40. https:// doi.org/10.2308/ bria-51457

Cameran, M., Negri, G., \& Pettinicchio, A.K. (2015). The audit mandatory rotation rule: The state of the art. The Journal of Financial Perspectives, 3(2), $1-25$.

Carey, P., \& Simnett, R. (2006). Audit partner tenure and audit quality. The Accounting Review, 81(3), 653-676. https://doi.org/10.2308/accr.2006. 81.3.653 
Carson, E.A., Luc, A., \& Wong, L. (2014). The relative effects of audit partner tenure and audit firm tenure on audit quality. Paper presented at Accounting and Finance Association of Australia and New Zealand Conference, Melbourne, Australia, 1 July - 3 July.

Chen, C-Y., Lin, C-J., \& Lin, Y-C. (2008). Audit partner tenure, audit firm tenure, and discretionary accruals: Does long auditor tenure impair earnings quality? Contemporary Accounting Research, 25(2), 415-444. https://doi. org/10.1506/car.25.2.5

Chen, S., Sun, S.Y.J, \& Wu, D. (2010). Client importance, institutional improvements, and audit quality in China: An office and individual auditor level analysis. The Accounting Review, 85(1), 127-158. https://doi.org/10.2308/ accr.2010.85.1.127

Cheng, P., Aerts, W., \& Jorissen, A. (2010). Earnings management, asset restructuring, and the threat of exchange delisting in an earnings-based regulatory regime. Corporate Governance: An International Review, 18(5), 438456. https:/ / doi.org/10.1111/j.1467-8683.2009.00780.x

Chi, W., \& Huang, H. (2005). Discretionary accruals, audit-firm tenure and audit-partner tenure: Empirical evidence from Taiwan. Journal of Contemporary Accounting and Economics, 1(1), 65-92. https://doi.org/10.1016/ s1815-5669(10)70003-5

Chi, W., Huang, H., Liao, Y., \& Xie, H. (2009). Mandatory audit partner rotation, audit quality, and market perception: Evidence from Taiwan. Contemporary Accounting Research, 26(2), 359-391. https:/ / doi.org/10.1506/car.26.2.2

Church, B.K., Dai, N.T., Kuang, X.J., \& Liu, X. (2020). The role of auditor narcissism in auditor-client negotiations: Evidence from China. Contemporary Accounting Research, 37(3), 1756-1787. https://doi.org/10.1111/19113846.12565

Clayton, B.M., \& Staden, C.J. (2015). The impact of social influence pressure on the ethical decision making of professional accountants: Australian and New Zealand evidence. Australian Accounting Review, 25(4), 372-388. https://doi.org/10.1111/auar.12077

Davis, S., DeZoort, F.T., \& Kopp, L.S. (2006). The effect of obedience pressure and perceived responsibility on management accountants' creation of budgetary slack. Behavioral Research in Accounting, 18(1), 19-35. https://doi. org/10.2308/bria.2006.18.1.19

DeAngelo, L.E. (1981). Auditor size and audit quality. Journal of Accounting $\mathcal{E}$ Economics, 3(3), 183-199. https:/ / doi.org/10.1016/0165-4101(81)90002-1

DeChow, P.M., Sloan, R.G., \& Sweeney, A.P. (1995). Detecting earnings management. The Accounting Review, 70(2), 193-225.

DeZoort, F.T., \& Lord, A.T. (1994). An investigation of obedience pressure effects on auditors' judgements. Behavioral Research in Accounting, 6 (1), 1-30.

Du, X., \& Lai, S. (2018). Financial distress, investment opportunity, and the contagion effect of low audit quality: Evidence from China. Journal of Business Ethics, 147(3), 565-593. https:/ / doi.org/10.1007/s10551-015-2986-5 
Firth, M., Rui, O.M., \& Wu, X. (2012). How do various forms of auditor rotation affect audit quality? Evidence from China. The International Journal of Accounting, 47(1), 109-138. https:// doi.org/10.1016/j.intacc.2011.12.006

Gong, G.M., Xiao, L., Xu, S., \& Gong, X. (2017). Do bond investors care about engagement auditors' negative experiences? Evidence from China. Journal of Business Ethics, 158, 779-806. https:// doi.org/10.1007/s10551-017-3737-6

Hofstede, G. (1980). Culture's consequences - international differences in work-related values. Sage.

Hofstede, G. (1991). Culture and organizations: Software of the mind. McGraw-Hill.

Kim, J-B, Min, C., \& Yi, C.H. (2004). Selective auditor rotation and earnings management: Evidence from Korea (Working paper). https://papers.ssrn. com/sol3/papers.cfm?abstract_id $=560522$

Kothari, S.P., Leone, A.J., \& Wasley, C.E. (2005). Performance matched discretionary accrual measures. Journal of Accounting and Economics, 39(1), 163-197. https://doi.org/10.1016/j.jacceco.2004.11.002

Lennox, C.S., Wu, X., \& Zhang, T. (2014). Does mandatory rotation of audit partners improve audit quality? The Accounting Review, 89(5), 1775-1803. https://doi.org/10.2308/accr-50800

Litt, B., Sharma, D.S., Simpson, T., \& Tanyi, P.N. (2014). Audit partner rotation and financial reporting quality. Auditing: A Journal of Practice $\mathcal{E}$ Theory, 33(3), 59-86. https://doi.org/10.2308/ajpt-50753

Liu, S. (2017). An empirical study: Auditors' characteristics and audit fee. Open Journal of Accounting, 6(2), 52-70. https://doi.org/10.4236/ojacct. 2017.62005

Manry, D.L., Mock, T.J., \& Turner, J.L. (2008). Does increased audit partner tenure reduce audit quality? Journal of Accounting, Auditing \& Finance, 23(4), 553-572. https://doi.org/10.1177/0148558x0802300406

Milgram, S. (1974). Obedience to authority. Harper \& Row.

Sharma, D.S., Tanyi, P.N., \& Litt, B.A. (2017). Costs of mandatory periodic audit partner rotation: Evidence from audit fees and audit timeliness. Auditing: A Journal of Practice \& Theory, 36(1), 129-149. https://doi.org/10.2308/ajpt51515

Stewart, J., Kent, P., \& Routledge, J. (2016). The association between audit partner rotation and audit fees: Empirical evidence from the Australian market. Auditing: A Journal of Practice $\mathcal{E}$ Theory, 35(1), 181-197. https://doi. org/10.2308/ajpt-51173

Wang, X., Wang, Y., Yu, L., Zhao, Y., \& Zhang, Z. (2015). Engagement audit partner experience and audit quality. China Journal of Accounting Studies, 3(3), 230-253. https://doi.org/10.1080/21697213.2015.1055776

Wang, Y., Yu, L., \& Zhao, Y. (2015). The association between audit-partner quality and engagement quality: Evidence from financial report misstatements. Auditing: A Journal of Practice \& Theory, 34(3), 81-111. https://doi.org/10.2308/ajpt-50954 
Relative Influences of Review and Engagement Auditor Rotation on Audit Quality

Xiao, T., Geng, C., \& Yuan, C. (2020). How audit effort affects audit quality: An audit process and audit output perspective. China Journal of Accounting Studies, 13(1), 109-127. https:// doi.org/10.1016/j.cjar.2020.02.002

Zhao, Y., Xu, N., Zhou, D., \& Chan, K.C. (2020). Audit partner rotation and negative information hoarding: Evidence from China. Accounting $\mathcal{E}$ Finance, 60(5), 4693-4722. https:// doi.org/10.1111/acfi.12676 
